\title{
EVALUASI PROGRAM PENDIDIKAN DAN PELATIHAN CALON KEPALA SEKOLAH DI KABUPATEN KAYONG UTARA PROVINSI KALIMANTAN BARAT (Studi Evaluatif Model CIPPO Pasca Pendidikan dan Pelatihan)
}

Isjuandi

SMA Negeri I Sukadana

Kayong Utara,

Kalimantan Barat

\section{Anan Sutisna}

Universitas Negeri

Jakarta
Alamat Korespondensi Jl. Manunggal RT. I0. RW. OI Desa Sutera

Kec. Sukadana, Kayong Utara, Kalbar. Kode Pos 7852

e-mail: uning26@yahoo.com isjuandispd@gmail.com

\section{ABSTRACT}

This study aims to evaluate education and training programs prospective principle in the education office of Kayong Utara District West Kalimantan Province. This study used a descriptive evaluative method CIPPO evaluation model developed by Stufflebeam and his colleagues and refined by Gilbert Sax. Data were collected with instrument interview, questioner, and document study. The subject of this study is the representation of all alumni of graduates of education and training of prospective principal from 2012 to 2015 in the education offices of Kayong Utara District West Kalimantan Province. The results of this research evaluation seen from five aspects, including: I) context, with relevant results for the legal basis, management design, and training program objectives. 2) input, related to training participants, curriculum and funding conformity with relevant results for sub aspect of program organizers with very good category (82,50\%), resource persons/facilitators with very good category $(79,69 \%)$, and infrastructure facilities with good category $(71,74 \%)$. 3) result of process, $77,92 \%$ with very good category for time allocation, result of suitability of curriculum and teaching material with good category $(74,40 \%)$, results of conformity of procedures and methods, monitoring and evaluation and process assessments relevant to technical guidelines and candidates for principals. 4) product evaluation results, related to the achievement of objectives that include competence in the form of relevant knowledge, attitudes and behavior competence with good category $(83,04 \%)$, skills with good category (75,89\%), and appointment as high school principle (86,30\%). 5) results of evaluation of outcomes, related to program impact, that is the performance of graduates after appointment have positive effect with very good category $(75,93 \%)$.

\section{Keywords}

education and training, prospective principals, CIPPO models.

\section{ABSTRAK}

Penelitian ini bertujuan untuk mengevaluasi program pendidikan dan pelatihan calon kepala sekolah di Dinas Pendidikan Kabupaten Kayong Utara Provinsi Kalimantan Barat. Penelitian ini menggunakan evaluasi deskriptif dengan model evaluasi CIPPO yang dikembangkan oleh Stufflebeam dan koleganya dan disempurnakan oleh Gilbert Sax. Data dikumpulkan dengan menggunakan instrumen wawancara, kuisioner, dan studi dokumen. Subjek pada penelitian ini adalah perwakilan semua angkatan alumni lulusan Pendidikan dan Pelatihan Calon Kepala Sekolah dari tahun 2012 sampai 2015 di Dinas Pendidikan Kabupaten Kayong Utara Provinsi Kalimantan Barat. Hasil evaluasi penelitian ini dilihat dari lima aspek, meliputi: I) context, dengan hasil relevansi untuk landasan hukum, rancangan manajemen dan tujuan program diklat. 2) Input, terkait peserta diklat, kesesuaian kurikulum dan pembiayaan dengan hasil relevan untuk sub aspek penyelenggara program dengan kategori sangat baik (82,50\%), narasumber/fasilitator dengan kategori sangat baik $\mathbf{7 9 , 6 9 \% )}$ dan sarana prasarana dengan kategori baik (7I,74\%). 3) hasil proses, 77,92\% dengan kategori sangat baik untuk alokasi waktu, hasil kesesuaian kurikukum dan bahan ajar dengan kategori baik (74,40\%), hasil kesesuaian prosedur dan metode, monitoring dan evaluasi dan penilaian proses relevan dengan petunjuk teknis dan pedoman 
pendidikan dan pelatihan calon kepala sekolah. 4) hasil evaluasi product, terkait pencapaian tujuan yang meliputi kompetensi yang berupa pengetahuan relevan, kompetensi sikap dan perilaku dengan kategori baik $(83,04 \%)$, keterampilan dengan kategori baik $(75,89 \%)$, dan pengangkatan sebagai kepala sekolah dengan kategori tinggi (86,30\%). 5) hasil evaluasi outcomes, terkait dampak program, yakni: kinerja lulusan setelah diangkat berpengaruh positif dengan kategori sangat baik $(75,93 \%)$.

\section{Kata Kunci}

Pendidikan dan Pelatihan, Calon Kepala Sekolah, Model CIPPO

\section{Pendahuluan}

Dalam upaya mewujudkan sekolah yang mampu membentuk insan Indonesia yang cerdas dan kompetitlf, kepala sekolah sebagai pimpinan di sekolah merupakan faktor penyumbang keberhasilan upaya penguatan tata kelola, akuntabilitas dan pencitraan publik. Keberhasilan kepala sekolah dalam meningkatkan kualitas pendidikan di sekolah tidak terlepas dari kompetensl dan kemampuannya menjalankan tugas, peran, dan fungsinya sebagai pimpinan,

Lingkungan pembelajaran yang kondusif di sebuah sekolah, sangat dipengaruhi oleh manajemen sekolah. Kepala sekolah memang bukan satu-satunya faktor, karena peran guru dan tenaga kependidikan lainnya juga sama pentingnya. Namun, dalam kaitannya dengan manajemen sekolah, kepala sekolah adalah indikator kuat dalam manajemen sekolah. Oleh sebab itu, para calon kepala sekolah harus disiapkan sebaik mungkin agar dapat mengelola unit kerjanya secara kreatif dan produktif.

Sebagaimana tercantum dalam Permen diknas No. 13 Tahun 2007 dinyatakan bahwa seorang kepala sekolah/madrasah diharapkan memiliki kompetensi kepribadian, manajerial, kewirausahaan, supervisi, dan sosial. Pada kenyataannya, tidak semua kepala sekolah/ madrasah menguasai seluruh kompetensi secara utuh. Terdapat kecenderungan kepala sekolah hanya menguasai beberapa kompetensi saja.

Hal tersebut di atas, dibuktikan dengan hasil survei tahun 2007 oleh Direktorat Tenaga Kependidikan menunjukkan bahwa rata-rata kompetensi kepala sekolah baru mencapai $54,88 \%$, sehingga dikategorikan masih lemah. Penguasaan kompetensi kepribadian (67,3\%), manajerial (47,I\%), kewirausahaan $(55,3 \%)$, supervisi (40,4l\%), dan sosial (64,2\%) (Kemendikbud, Juklak Pemerolehan sertifikat dan NUKS, 2013: I).

Sesuai dengan Permendiknas Nomor 13 Tahun 2007 menyatakan bahwa seorang kepala sekolah/madrasah harus memiliki kompetensi kepribadian, manajerial, kewirausahaan, supervisi, dan sosial. Meskipun calon kepala sekolah/ madrasah sudah lulus dari tahap rekrutmen, diyakini bahwa penguasaan kompetensi yang dimiliki oleh para calon kepala sekolah/madrasah tidaklah sempurna. Oleh karena itu, Peraturan Menteri Pendidikan Nasionai No. 28 Tahun 20I0, Pasal 3 ayat I (satu), tentang Tugas Tambahan Guru Sebagai Kepala Sekolah menyatakan bahwa untuk memperoleh sertifikat kepala sekolah, calon kepala sekolah harus menempuh 2 tahapan, yakni: tahap rekrutmen dan tahap pendidikan dan pelatihan calon kepala sekolah/madrasah. Rekrutmen meliputi proses pengusulan calon, seleksi administratif, dan seleksi akademik. Sedangkan pendidikan dan pelatihan adalah proses pemberian pengalaman pembelajaran teoretik maupun praktik kepada para calon yang telah lulus rekrutmen (Permendiknas No. 28 Tahun 20I0)

Dengan melakukan program penyiapan kepala sekolah/madrasah yang benar akan menghasilkan calon kepala sekolah/madrasah yang kompeten. Kepala sekolah yang kompeten akan mampu mengembangkan dan memberdayakan dirinya. Kepala sekolah yang kompeten akan memacu peningkatan kinerja sekolah yang dipimpinnya ke arah peningkatan mutu, relevansi, dan daya saing pendidikan.

Menurut Mulyasa banyaknya kepala sekolah yang masih kurang memenuhi standar, tidak lepas dari proses rekrutmen dan pengangkatan kepala 
Isjuandi

Anan Sutisna
Evaluasi Program Pendidikan dan Pelatihan Calon

Kepala Sekolah di Kabupaten Kayong Utara Provinsi sekolah disejumlah daerah bersifat penunjukan langsung yang tergesa-gesa. Proses dari guru untuk menjadi kepala sekolah hanya beberapa hari saja, bahkan beberapa jam melalui seleksi biasa seperti seleksi CPNS (Mulyasa, 20II: I8).

Pendapat lebih tegas dikemukakan Suhardiman bahwa rekrutmen kepala sekolah di era desentralisasi sangat kental dengan nuansa politik di tingkat daerah. Rekrutmen kepala sekolah disamakan dengan pemilihan pejabat struktural. Akibat negatifnya, ketika menjadi kepala sekolah, perilakunya seperti birokrat yang harus selalu loyal pada atasannya (Budi Suhardiman, 2012: 58).

Pada hakikatnya kepala sekolah merupakan jabatan profesional yang harus mengedepankan prinsip-prinsip akademis dalam mewujudkan mutu pendidikan di sekolah yang dipimpinnya. Para calon kepala sekolah perlu dibekali dengan kompetensi yang memungkinkan mereka menjalankan tugasnya dengan baik. Mereka dituntut accountable atas keputusan-keputusan yang diambil dan dilaksanakan. Melalui pendidikan dan pelatihan, para calon kepala sekolah akan dibekali dengan sejumlah kompetensi dasar yang harus dikuasai dan dimiliki. Kompetensi lainnya dapat dikembangkan setelah menduduki jabatan sebagai kepala sekolah.

Sesuai amanat Permendiknas Nomor 28 Tahun 2010 Pasal 3 ayat 2 (dua), tahap awal program penyiapan calon kepala sekolah di Kabupaten Kayong Utara Provinsi Kalimantan Barat, dimulai dengan proses rekrutmen calon kepala sekolah yang dilaksanakan oleh Dinas Pendidikan Kabupaten Kayong Utara Provinsi Kalimantan Barat, dengan memperhatikan analisis proyeksi kebutuhan kepala sekolah untuk lima tahun ke depan. Hal ini dimaksudkan agar Kabupaten Kayong Utara Provinsi Kalimantan Barat memiliki jumlah calon kepala sekolah yang mencukupi untuk memenuhi kebutuhan formasi.

Adapun mekanisme rekrutmen yang dilakukan Dinas Pendidikan Kabupaten Kayong Utara Provinsi Kalimantan Barat adalah sebagai berikut:

a. Pengumuman rekrutmen calon kepala sekolah melalui surat resmi dari Dinas Pendidikan yang dikirim ke I54 sekolah mulai dari tingkat SD, SMP, SMA, dan SMK. b. Pengajuan usulan calon kepala sekolah oleh pihak sekolah.

c. Seleksi Administratif.

d. Seleksi Akademik.

Tahap berikutnya yang dilakukan setelah rekrutmen adalah pelaksanaan pendidikan dan pelatihan calon kepala sekolah. Tahapan ini sepenuhnya menjadi tugas dan wewenang Dinas Pendidikan Kabupaten Kayong Utara Provinsi Kalimantan Barat sebagai penyelenggara yang bermitra dengan LPMP Provinsi Kalimantan Barat dan LPPKS sebagai narasumber/fasilitator dalam pelaksanaan program pendidikan dan pelatihan calon kepala sekolah ini. Program pendidikan dan pelatihan penyiapan calon kepala sekolah dilakukan dengan tahapan:

I) Pelaksanaan In Service Learning I (Diklat).

2) Pelaksanaan On The lob Learning (Magang).

3) In Service Learning 2 (Penyampaian hasil).

Berdasarkan pemikiran di atas, maka dilakukan penelitian tentang "Evaluasi Program Pendidikan dan Pelatihan Calon Kepala Sekolah di Kabupaten Kayong Utara Provinsi Kalimantan Barat", dengan setting penelitian adalah guru-guru dan kepala sekolah yang terpilih dan diusulkan dari tingkat SD, SMP, SMA, dan SMK, di Kabupaten Kayong Utara Provinsi Kalimantan Barat sebagai peserta program pendidikan dan pelatihan calon kepala sekolah SD, SMP, SMA, dan SMK dalam rangka penyiapan calon kepala sekolah di Kabupaten Kayong Utara Provinsi Kalimantan Barat dari tahun 2012 sampai dengan tahun 2015 yang berjumlah sekitar 73 orang yang telah lulus program pendidikan dan pelatihan calon kepala sekolah dengan rincian sebagai berikut: tahun 2012 sebanyak 13 orang, tahun 2013 sebanyak 20 orang, tahun 2014 sebanyak 18 orang, dan tahun 2015 sebanyak 22 orang dari I54 sekolah di Kabupaten Kayong Utara Provinsi Kalimantan Barat.

Selanjutnya, kendala dalam pelaksanaan program pendidikan dan pelatihan calon kepala sekolah berupa kurangnya motivasi peserta, fasilitas dan pembiayaan atau pendanaan dalam pelaksanaan program pendidikan, dan pelatihan calon kepala sekolah dibebankan sepenuhnya kepada Dinas Pendidikan Kabupaten Kayong 
Isjuandi

Anan Sutisna

Utara Provinsi Kalimantan Barat tanpa memungut biaya dari peserta pendidikan dan pelatihan calon kepala sekolah, seharusnya dapat memberikan motivasi yang tinggi bagi calon kepala sekolah dalam mengikuti dan menyelesaikan program pendidikan dan pelatihan calon kepala sekolah, namun masih ada calon kepala sekolah dinyatakan gagal atau tidak lulus karena tidak dapat menyelesaikan pendidikan dan pelatihan sampai tuntas sesuai dengan aturan yang disepakati. Sehingga harus gagal dalam penyiapan calon kepala sekolah. Hal ini tentu saja berdampak pada kekurangan target penyiapan kepala sekolah dan kerugian pembiayaan yang dikeluarkan oleh Dinas Pendidikan Kabupaten Kayong Utara Provinsi Kalimantan Barat dalam pelaksanaan program pendidikan dan pelatihan calon kepala sekolah.

Permasalahan lain adalah outcome(s) setelah mengikuti program pendidikan dan pelatihan calon kepala sekolah seharusnya bermanfaat bagi calon kepala sekolah dalam menumbuh kembangkan pengetahuan, sikap, dan keterampilan pada dimensi-dimensi kompetensi kepribadian, manajerial, kewirausahaan, supervisi, dan sosial, namun ditemukan kepala sekolah yang masih belum mampu menerapkan kompetensi yang dimilikinya sebagai seorang kepala sekolah. Tidak ada peningkatan prestasi kerja, dan tidak memberikan kontribusi yang signifikan dengan kompetensi yang dimiliki kepala sekolah. Realitanya bahwa program yang baik dalam pelaksanaannya dapat dilihat adanya peningkatan kualitas kepala sekolah setelahnya, baik kompetensi, prestasi kerja, serta memberikan kontribusi positif di lingkungan kerjanya.

Berdasarkan permasalahan di atas, evaluasi program pendidikan dan pelatihan calon kepala sekolah SD, SMP, SMA, dan SMK dalam rangka penyiapan calon kepala sekolah di Kabupaten Kayong Utara Provinsi Kalimantan Barat dianggap penting untuk mengetahui hasil evaluasi yang menyeluruh supaya hasilnya dapat digunakan sebagai bahan rekomendasi dan pertimbangan kepada Dinas Pendidikan Kabupaten Kayong Utara Provinsi Kalimantan Barat.

Hasil evaluasi bermuara pada peningkatan mutu pendidikan melalui peningkatan kompetensi kepala sekolah, yang mana outcome(s) dari program ini diharapkan sebagai pioner yang
Evaluasi Program Pendidikan dan Pelatihan Calon Kepala Sekolah di Kabupaten Kayong Utara Provinsi

Kalimantan Barat

dijadikan sebagai "Role Model" atau teladan sebagai kepala sekolah yang berkompetensi memiliki inovasi dan kreatifitas pada bidang profesinya (Permendikbud, No. 13 Tahun 2007). Dengan begitu, evaluasi dapat dilihat apakah outcome(s) dari program pendidikan dan pelatihan calon kepala sekolah dalam rangka penyiapan calon kepala sekolah secara langsung dapat membawa perubahan pada organisasi lingkungan kerja terhadap peningkatan mutu dan pelayanan pendidikan.

Menurut Mulyatiningsih, penelitian evaluasi program berisi kegiatan pengumpulan data dan informasi untuk membuat keputusan tentang pengumpulan data dan informasi untuk membuat keputusan tentang program (melanjutkan, memperluas, memperbaiki, atau menghentikan) program yang sedang berjalan (Endang Mulytiningsih, Bandung, 2003: 109)

Dengan demikian, penelitian evaluasi program merupakan kegiatan sistematis untuk mengumpulkan, mengolah, dan menganalisis serta menyampaikan data, baik berupa fakta, keterangan, maupun informasi, sebagai masukan untuk pengambilan keputusan terhadap suatu program. Dalam hal ini, penelitian evaluasi program mengandung tiga unsur penting, yaitu: (I) kegiatan sistematis, (2) data, dan (3) pengambilan keputusan. Pertama, kegiatan sistematis berarti evaluasi program dilaksanakan melalui prosedur yang tertib berdasarkan kaedahkaedah ilmiah. Kedua, data yang dikumpulkan sebagai fokus evaluasi program melalui kegiatan pengumpulan, pengolahan, analisis, dan penyajian dengan menggunakan pendekatan, model, metode, dan teknik ilmiah. Ketiga, pengambilan keputusan berarti bahwa data yang disajikan akan bernilai apabila menjadi masukan berharga untuk proses pengambilan keputusan tentang alternatif yang akan diambil terhadap program.

Dengan melakukan evaluasi terhadap program pendidikan dan pelatihan calon kepala sekolah dalam rangka penyiapan calon kepala sekolah ini diharapkan bagi Dinas Pendidikan Kabupaten Kayong Utara Provinsi Kalimantan Barat khususnya pengambil kebijakan dapat dijadikan sebagai bahan pertimbangan dan literatur dalam rangka pengangkatan kepala sekolah serta 
Isjuandi

Anan Sutisna

peningkatan mutu program di masa yang akan datang.

\section{Metode Penelitian}

Pendekatan penelitian yang digunakan dalam penelitian ini, yaitu: deskriptif kualitatif. Penelitian deskriptif kualitatif merupakan penelitian yang termasuk dalam jenis penelitian kualitatif. Tujuan dari penelitian ini adalah mengungkap fakta, keadaan, fenomena, variabel, dan keadaan yang teriadi saat penelitian berjalan dan menyuguhkan apa adanya.

Metode penelitian pada dasarnya merupakan cara ilmiah untuk mendapatkan data dengan tujuan dan kegunaan tertentu. Pada penelitian evaluasi ini dengan pendekatan kualitatif dipilih sebagai cara untuk memperoleh informasi atau data di mana evaluator sebagai instrumen kunci memperoleh data melalui indepth interview (wawancara mendalam), observasi, angket (kuisioner), dan studi dokumentasi.

Pada penelitian evaluasi program pendidikan dan pelatihan calon kepala sekolah di Kabupaten Kayong Utara Provinsi Kalimantan Barat, telah disebutkan bahwa evaluator menggunakan pendekatan evaluasi model CIPPO, kisi-kisi instrumen yang digunakan pada evaluasi yang dilakukan pada aspek atau komponen Context, Input, Process, Output, dan Outcome(s) yang digunakan untuk memperoleh informasi.

Metode kualitatif dalam evaluasi dilakukan pada tiap-tiap aspek tahapan atau komponen, informasi atau data terkait penilaian evaluator adalah:

a. Landasan hukum atau landasan konseptual, rancangan manajemen dan tujuan pelaksanaan program pendidikan dan pelatihan calon kepala sekolah terkait dengan komponen evaluasi konteks.

b. Efektifitas program yang terkait dengan komponen evaluasi input (masukan) seperti: peserta, penyelenggara, narasumber, kurikulum, sarana prasarana, dan sumber dana/pembiayaan.

c. Aktifitas penyelenggaraan pendidikan yang terkait dengan process pelaksanaan program pendidikan dan pelatihan calon kepala sekolah, yakni: alokasi waktu, kesesuaian
Evaluasi Program Pendidikan dan Pelatihan Calon Kepala Sekolah di Kabupaten Kayong Utara Provinsi

Kalimantan Barat

kurikulum, prosedur dan metode pembelajaran, monitoring dan evaluasi, dan proses penilaian.

d. Keberhasilan pencapaian tujuan dalam peningkatan kinerja lulusan dan pengangkatan /penempatan lulusan program pendidikan dan pelatihan calon kepala sekolah, yakni: penguasaan pengetahuan, sikap, dan keterampilan merupakan komponen evaluasi product.

e. Dampak dari program pendidikan dan pelatihan calon kepala sekolah berupa kinerja lulusan mempunyai pengaruh positif dan bermanfaat terhadap instansi tempat di mana lulusan ditugaskan, warga sekolah dan masyarakat pada umumnya merupakan komponen evaluasi outcome(s).

Teknik purposive sampling digunakan untuk menjaring informasi dalam evaluasi program ini. Subyek penelitian berkaitan dengan orang-orang yang terlibat dan mengetahui, atau menjadi pelaku dalam kegiatan program pendidikan dan pelatihan calon kepala sekolah. Sebagai informan kunci, responden atau sampling penelitian meliputi: I. Kepala Dinas Pendidikan Kabupaten Kayong Utara Provinsi Kalimantan Barat sebagai penyelenggara program; 2. Kepala sub bagian Aparatur Dinas Pendidikan Kabupaten Kayong Utara Provinsi Kalimantan Barat sebagai panitia kegiatan; 3. Pengawas Sekolah; 4. Wakil Kepala Sekolah; 5. Rekan sejawat (guru), calon kepala sekolah (peserta lulusan), dan siswa.

Model riset evaluasi yang dipakai, yaitu: model CIPPO yang dikembangkan oleh Stufflebeam dan koleganya dan disempurnakan oleh Gilbert Sax. Evaluasi model CIPPO terdiri dari lima komponen, yaitu: context, input, process, product, and outcome(s). Keunggulan model ini adalah memberikan suatu kajian yang komprehensif dari suatu fenomena sosial yang sedang diamati. Model CIPPO berorientasi pada pengambilan keputusan (decision oriented).

Teknik pengumpulan data dilakukan dengan wawancara, angket, observasi, dan studi dokumen. Teknik analisis data yang digunakan adalah deskriptif kualitatif. 
Isjuandi

Anan Sutisna

\section{Hasil Penelitian dan Pembahasan}

Hasil yang diperoleh dari evaluasi program pendidikan dan pelatihan calon kepala sekolah yang diselenggarakan oleh Dinas Pendidikan Kabupaten Kayong Utara Provinsi Kalimantan Barat dengan menggunakan model CIPPO, maka hasil evaluasi yang dipaparkan meliputi deskripsi context; input; process, product; dan outcome(s) sebagai berikut:

\section{a. Context (Dasar Hukum)}

Komponen konteks yang dievaluasi meliputi landasan hukum program pendidikan dan pelatihan calon kepala sekolah, rancangan manajemen, dan tujuan penyelenggaraan program pendidikan dan pelatihan calon kepala sekolah.

\section{I) Landasan Hukum}

Pada aspek ini peneliti melakukan wawancara terhadap beberapa responden untuk pengetahuan dan pemahamannya tentang regulasi maupun peraturan perundang-undangan yang dikeluarkan oleh pemerintah pusat yang merupakan ketentuan yang memberikan pijakan rasional di lapangan sebagai penjabaran Permendiknas Nomor 28 Tahun 2010 tentang seleksi sampai pada pendidikan dan pelatihan calon kepala sekolah. Diantaranya responden dari narasumber, penyelenggara, pejabat yang berwenang, dan pengawas di Dinas Pendidikan dan Kebudayaan Kabupaten Kayong Utara Provinsi Kalimantan Barat, semuanya memberikan jawaban cukup memuaskan. Kemudian beberapa alumni pendidikan dan pelatihan calon kepala sekolah serta guru sejawat di sekolah para calon kepala sekolah, hasilnya adalah masih terdapat 20 orang calon kepala sekolah dan beberapa guru yang peneliti tanyakan, apa landasan hukum pelaksanaan pendidikan dan pelatihan termasuk 4 orang kepala sekolah dan I orang pengawas sekolah, ada dari mereka belum mengetahuinya. Hal ini menunjukkan bahwa di kalangan para pengawas, kepala sekolah, mapun guru di sekolah ternyata belum dilakukan sosialisasi secara maksimal dan menyeluruh.

Program pendidikan dan pelatihan calon kepala sekolah diselenggarakan berdasarkan kebutuhan dan tuntutan undang-undang untuk memberikan pelayanan pendidikan kepada seluruh warga negara guna peningkatan mutu, relevansi, dan daya saing. Diperkuat dengan Peraturan Pemerintah (PP) Nomor 32 Tahun 2013 sebagai perubahan dari Peraturan Pemerintah (PP) Nomor 19 Tahun 2005 Tentang Standar Nasional Pendidikan (SNP), Peraturan Menteri Pendidikan Nasional Nomor 13 Tahun 2007 tentang Standar Kualifikasi dan Kompetensi Kepala Sekolah, dan Peraturan Menteri Pendidikan Nasional Nomor 28 Tahun 2010 Tentang Guru Yang Diberi Tugas Tambahan sebagai Kepala Sekolah, Petunjuk Pelaksanaan dan Petunjuk Teknis pelaksanaan pendidikan dan pelatihan calon kepala sekolah.

\section{2) Rancangan Manajemen}

Berdasarkan hasil analisis dokumen pada Dinas Pendidikan Kabupaten Kayong Utara Provinsi Kalimantan Barat, bahwa jumlah sekolah pada semua jenjang di enam kecamatan dengan tenaga kepala sekolah merupakan faktor penting yang menjadi latar belakang dari rancangan manajemen untuk perlunya pelaksanaan program pendidikan dan pelatihan calon kepala sekolah di Kabupaten Kayong Utara Provinsi Kalimantan Barat, yang menjadi acuan dalam menghadapi tuntutan regulasi undang-undang dan peningkatan kualitas pelayanan pendidikan dengan merumuskan suatu rancangan manajemen berdasarkan hasil analisis terhadap kebutuhan kepala sekolah yang ada, yaitu: tidak memiliki sertifikat sebagai kepala sekolah, rendah (buruknya) kompetensi yang dimiliki kepala sekolah, masa kerja dan pensiun, berhalangan tetap (meninggal atau mengundurkan diri), serta pemutasian ke sekolah lain maupun pada instansi yang lebih tinggi.

Dari gambaran data tersebut di atas menunjukkan bahwa jumlah sekolah secara keseluruhan SD, SMP, SMA, dan SMK negeri sebanyak I54 sekolah. Jumlah sekolah tersebut telah memiliki kepala sekolah. Namun demikian sesuai dengan analisis kebutuhan kepala sekolah untuk 5 tahun ke depan, maka kepala sekolah masih dibutuhkan sebanyak II2 untuk semua jenjang Pendidikan. 


\section{3) Tujuan Penyelenggaraan Program}

Tujuan khusus program untuk menumbuhkembangkan pengetahuan, sikap, dan keterampilan pada dimensi-dimensi kompetensi kepribadian, manajerial, kewirausahaan, supervisi, dan sosial bagi calon kepala sekolah. Dari tujuan yang telah ditetapkan dalam dokumen tersebut masih terasa belum lengkap jika belum terbukti dapat dicapai dalam pelaksanaan pendidikan dan pelatihan, namun setelah peneliti melakukan wawancara dengan beberapa sumber, yaitu: kepala sekolah dan pengawas sebagai responden maka pendapat responden sama komentarnya, yakni: para calon kepala sekolah yang telah mengikuti pendidikan dan pelatihan calon kepala sekolah memiliki kompetensi yang lebih baik dari sebelumnya. Kompetensi dimaksud adalah pengetahuan, sikap, dan keterampilan kepemimpinan sebagai kepala sekolah. Hal ini menunjukkan bahwa tujuan pendidikan dan pelatihan calon kepala sekolah telah tercapai.

Selain wawancara kepala sekolah dan pengawas sekolah, hal senada juga diutarakan oleh salah satu penyelenggara maupun beberapa narasumber dan fasilitator pendidikan dan pelatihan, saat peneliti mewawancarai mereka dan ternyata pendapat mereka tentang hasil pendidikan dan pelatihan memuaskan karena semuanya dinyatakan lulus dengan kategori baik. Artinya saat penilaian para peserta rata-rata dapat menguasai materi dan dapat mempresentasikan portofolio mereka.

\section{b. Input (Masukan)}

Evaluasi input (masukan) mencakup analisis persoalan yang berhubungan dengan pemanfaatan sumber-sumber yang tersedia dan alternatif strategi yang harus dipertimbangkan untuk mencapai suatu program. Selain itu untuk mengidentifikasi dan menilai kapabilitas sistem, alternatif strategi, desain prosedur untuk strategi implementasi, penjadwalan dan pemanfaatan pemilihan sumber daya, serta strategi implementasi rancangan program yang tepat agar dapat terlaksana secara efektif dan efisien. Dalam penelitian ini evaluasi pada komponen input program pendidikan dan pelatihan antara lain mengenai; karakteristik peserta pendidikan dan pelatihan calon kepala sekolah, karakteristik narasumber/fasilitator, kurikulum program diklat, sarana prasarana, dan pembiayaan pendidikan dan pelatihan calon kepala sekolah.

\section{I) Karakteristik Peserta}

Dalam program penyediaan calon kepala sekolah yang akan menjadi peserta pendidikan dan pelatihan terlebih dahulu harus lulus seleksi administrasi dan seleksi akademik serta memenuhi persyaratan yang telah ditetapkan oleh Lembaga Pengembangan dan Pemberdayaan Kepala Sekolah (LPPKS) sebagai penjabaran dari isi Permendiknas Nomor 28 Tahun 2010 yang dijadikan acuan oleh penyelenggara pendidikan dan pelatihan calon kepala sekolah. Persyaratan tersebut mutlak dan tidak dapat diganggu gugat, dengan kata lain, jika ada salah satu syarat yang tidak terpenuhi maka guru yang mencalonkan diri sebagai peserta seleksi calon kepala sekolah dianggap tidak memenuhi persyaratan untuk mengikuti pendidikan dan pelatihan calon kepala sekolah.

Secara keseluruhan dapat digambarkan dengan grafik lingkaran sebagai berikut:

Peserta Diklat Cakep Tahun 2012 s/d 2015

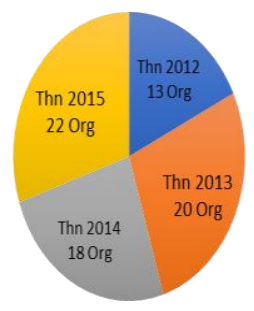

- Tahun 2012 -Tahun 2013 = Tahun 2014 "Tahun 2015

\section{2) Penyelenggara Program}

Penyelenggara pendidikan dan pelatihan calon kepala sekolah sesuai dengan ketentuan yang distandarkan dalam pelaksanaan kegiatan pendidikan dan pelatihan calon kepala sekolah. Oleh karena itu peneliti melakukan angket kepada 36 responden dari alumni calon kepala sekolah yang telah mengikuti pendidikan dan pelatihan untuk persiapan penyelenggara program 
Isjuandi

Anan Sutisna

dan kepada 40 orang responden dari calon kepala sekolah yang telah mengikuti pendidikan dan pelatihan untuk kemampuan penyelenggara dengan hasil seperti dapat dilihat pada grafik berikut:

\section{Kompetensi Penyelenggara/Panitia}

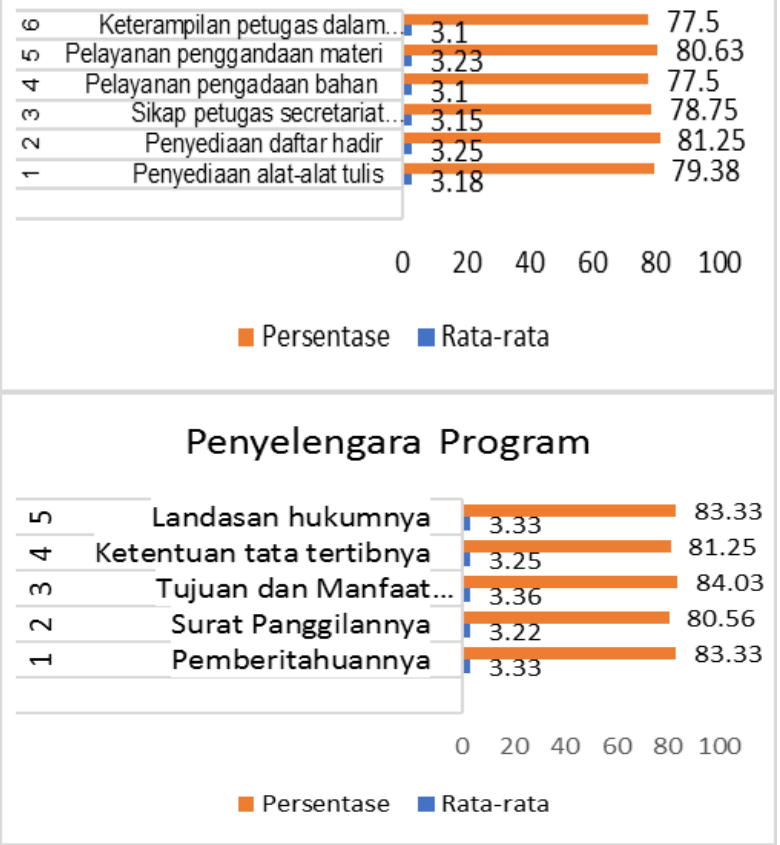

Berdasarkan data angket tersebut dapat disimpulkan bahwa penyelenggara program pendidikan dan pelatihan calon kepala sekolah untuk kesiapan penyelenggara memperoleh nilai rata-rata 3,30 dengan persentase $82,50 \%$ kategori sangat memuaskan. Sedangkan untuk kompetensi penyelenggara memperoleh nilai rata-rata 3,17 dengan persentase $79,17 \%$ sehingga dikategorikan memuaskan.

\section{3) Karakteristik Narasumber/Fasilitator}

Narasumber dan atau fasilitator pendidikan dan pelatihan calon kepala sekolah adalah widyaiswara dari LPMP Provinsi Kalimantan Barat yang memiliki kualifikasi sesuai dengan persyaratan yang ditetapkan oleh pemerintah.

Adapun unsur-unsur yang dinilai pada aspek ini meliputi: penguasaan materi, kemampuan dalam mempersiapkan materi ajar, latar belakang pendidikan, sistematika penyajian, kemampuan menyajikan, relevansi materi dengan tujuan,
Evaluasi Program Pendidikan dan Pelatihan Calon Kepala Sekolah di Kabupaten Kayong Utara Provinsi

Kalimantan Barat

penggunaan metode dan media pembelajaran, penggunaan bahasa, ketepatan menjawab pertanyaan peserta, kemampuan memotivasi peserta, kualitas bahan ajar, gaya, sikap, dan perilaku, kerapian dalam berbusana/penampilan, ketepatan waktu, kehadiran, penyajian materi, dan kerjasama antar fasilitator/narasumber. Data hasil angket diperoleh angka seperti terlihat pada grafik berikut:

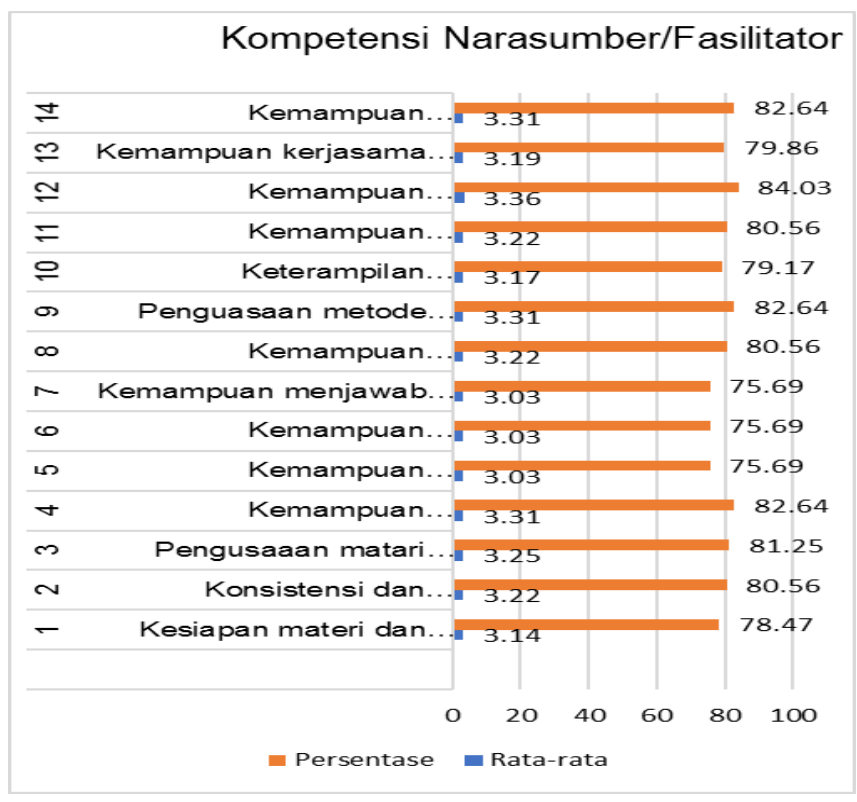

Secara keseluruhan dari hasil angket penelitian, untuk kompetensi narasumber dapat diperoleh nilai rata-rata sebesar 3,20 dengan persentase $79,69 \%$ maka termasuk kategori sangat baik.

\section{4) Kurikulum Pendidikan dan Pelatihan Calon Kepala Sekolah}

Kurikulum berkaitan dengan materi dan bahan ajar yang diberikan. Berdasarkan wawancara penulis dengan beberapa responden, yaitu: calon kepala sekolah yang telah mengikuti pendidikan dan pelatihan diperoleh informasi sebagai berikut:

Materi pendidikan dan pelatihan calon kepala sekolah yang diberikan sesuai dengan jenjang pendidikan, seperti untuk calon kepala sekolah SD materi yang diberikan sesuai dengan kepemimpinan kepala sekolah SD, calon kepala sekolah SMP materi yg diberikan juga sesuai dengan kepemimpinan sekolah SMP, dan 
seterusnya. Selain wawancara dengan calon kepala sekolah sebagai peserta pendidikan dan pelatihan, peneliti memperluas informasi lagi dengan sumber yang berbeda, yaitu: salah satu narasumber/fasilitator dan satu orang penyelenggara sehingga mudah untuk dilakukan triangulasi terhadap data yang diperoleh. Materimateri yang disusun dan diberikan tersebut adalah dalam rangka pengembangan kompetensi kepala sekolah, baik kompetensi kepribadian, manajerial, kewirausahaan, supervisi, dan sosial. Materi-materi yang diberikan dirangkum dalam modul yang disesuaikan dengan karakteristik peserta pendidikan dan pelatihan calon kepala sekolah.

Struktur kurikulum pendidikan dan pelatihan calon kepala sekolah di Dinas Pendidikan Kabupaten Kayong Utara Provinsi Kalimantan Barat sebagai berikut:

Struktur Kurikum In-Service Learning I

\begin{tabular}{|l|l|l|}
\hline NO & MATA DIKLAT & JUMLAH \\
\hline \multirow{3}{*}{ JAM }
\end{tabular}

Struktur Kurikulum On-The JoB Learning

\begin{tabular}{|l|l|l|}
\hline NO & MATA DIKLAT & $\begin{array}{l}\text { JUMLAH } \\
\text { JAM }\end{array}$ \\
\hline I & $\begin{array}{l}\text { Pelaksanaan rencana tindakan di } \\
\text { sekolah magang baik di sekolah } \\
\text { tempat calon kepala } \\
\text { sekolah/madrasah }\end{array}$ & $\begin{array}{l}3 \text { bulan } \\
(200 \mathrm{JP})\end{array}$ \\
\hline
\end{tabular}

Struktur Kurikulum In- Service Learning 2

NO MATA DIKLAT UUMLAH JAM

\begin{tabular}{|l|l|l|}
\hline A. & UMUM & \\
\hline I & Pembukaan & I JP \\
\hline
\end{tabular}

\begin{tabular}{|l|l|l|}
\hline B. & INTI & \\
\hline 1 & Penjelasan kriteria kelulusan & I JP \\
\hline 2 & $\begin{array}{l}\text { Presentasi hasil On the Job } \\
\text { Learning }\end{array}$ & I JP \\
\hline 3 & Penilaian Portofolio & I J JP \\
\hline C. & PENUNJANG & \\
\hline 1 & Refleksi Pelatihan & 3 JP \\
\hline 2 & Post-test & I JP \\
\hline 3 & Evaluasi/Penutupan & I JP \\
\hline & Jumlah & $30 ~ J P$ \\
\hline
\end{tabular}

\section{5) Sarana dan Prasarana Pendidikan dan Pelatihan Calon Kepala Sekolah}

Dalam penelitian ini evaluasi terhadap fasilitas sarana dan prasarana menggunakan metode angket dan wawancara dalam rangka mengetahui ketersediaannya. Metode angket peneliti menggunakan pedoman angket (cheklist) skala 4 (4 = sangat puas, $3=$ puas, $2=$ tidak puas dan $\mathrm{I}=$ sangat tidak puas) dan sampel yang diambil adalah 20 orang calon kepala sekolah dan 3 orang narasumber sebagai responden. Secara keseluruhan dapat dipaparkan dalam bentuk grafik sebagai berikut:

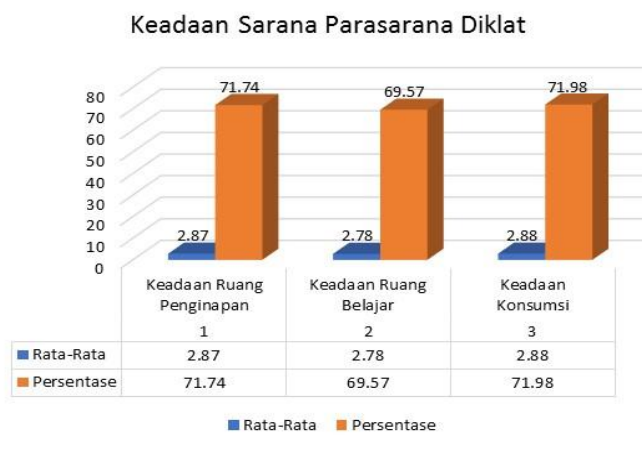

Pada grafik tersebut dapat disimpulkan bahwa fasilitas sarana dan prasarana secara keseluruhan telah memenuhi standar dan kriteria evaluasi, kecuali pada fasilitas ruang belajar perlu mendapat perhatian karena hasil penilaian terendah, yaitu: pada item kondisi ruang belajar dengan perolehan nilai rata-rata 2,65, persentase 66,30\%, pada fasilitas penginapan perlu mendapat perhatian yang lebih, yaitu: pada item keamanan dengan perolehan nilai rata-rata 2,70 persentase $67,39 \%$, dan pada fasilitas pelayanan konsumsi perlu mendapat perhatian lebih karena hasil penilaian masih 
Isjuandi

Anan Sutisna

rendah, yaitu: pada item variasi hidangan dengan perolehan nilai rata-rata 2,6I, persentase $65,22 \%$. Namun demikian bila dilihat secara keseluruhan pada tiap komponen sarana prasana maka diperoleh pula kesimpulan bahwa fasilitas ruang belajar masuk nilai puas dengan kategori baik. Sementara fasilitas penginapan peserta pendidikan dan pelatihan dan pelayanan konsumsi memperoleh penilaian puas dengan kategori baik.

\section{6) Pembiayaan}

Berdasarkan wawancara peneliti dengan penyelenggara dalam hal ini panitia dari Dinas Pendidikan Kabupaten Kayong Utara Provinsi Kalimantan Barat, yaitu: Ketua panitia pelaksana pendidikan dan pelatihan calon kepala sekolah diperoleh informasi sebagai berikut: Semua pembiayaan kegiatan ditanggung oleh Pemerintah Daerah Kabupaten Kayong Utara Provinsi Kalimantan Barat melalui Dinas Pendidikan Kabupaten Kayong Utara Provinsi Kalimantan Barat selaku penyelenggara yang tertuang dalam Rencana Kerja Anggaran (RKA) Dinas Pendidikan Kabupaten Kayong Utara Provinsi Kalimantan Barat tahun tahun 2012 sampai dengan tahun 2015.

\section{c. Process (Proses)}

Dalam tahap proses ada beberapa aspek yang akan dibahas sebagai hasil evaluasi di lapangan, antara lain: kesesuaian alokasi waktu pelaksanaan, kesesuaian kurikulum dan bahan ajar pendidikan dan pelatihan, dan kesesuaian prosedur dan metode pembelajaran pendidikan dan pelatihan.

\section{I) Kesesuaian Alokasi Waktu Pelaksanaan}

Pelaksanaan pendidikan dan pelatihan calon kepala sekolah/madrasah dengan durasi waktu sebagai berikut:
a) In-Service Learning I : 70 jpl (7 hari)
b) On-the-lob Learning : $200 \mathrm{jpl}$ (3 bulan)
c) In-Service Learning $2: 30 \mathrm{jpl}$ (3 hari)

Evaluasi Program Pendidikan dan Pelatihan Calon Kepala Sekolah di Kabupaten Kayong Utara Provinsi

Kalimantan Barat

Pemanfaatan alokasi waktu sesuai tahapan telah berjalan sesuai kriteria. Dapat dilihat pada grafik berikut:

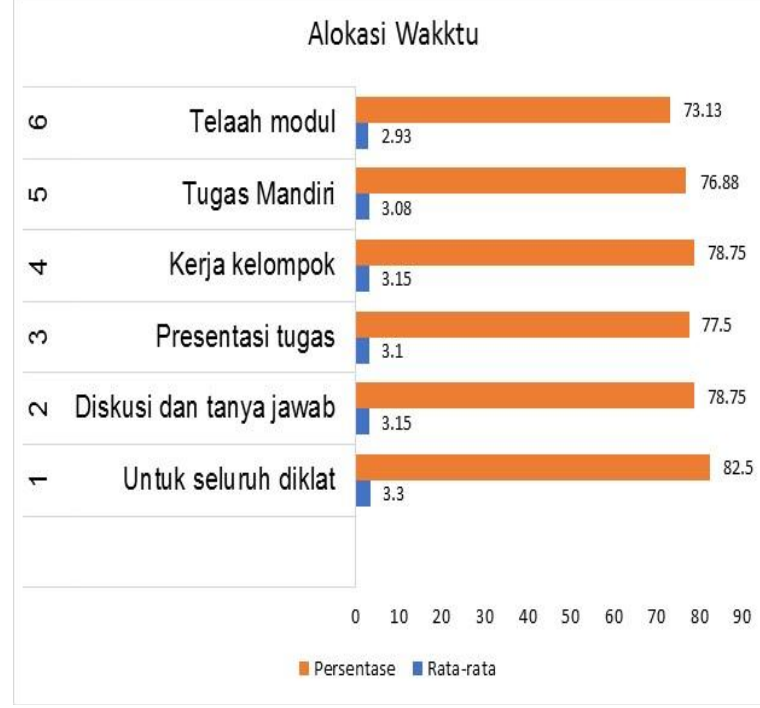

Evaluasi pada aspek pemanfaatan alokasi waktu yang telah ditentukan dalam struktur kurikulum telah dilaksanakan sesuai standar, di mana terlihat dari alokasi waktu yang paling banyak jam pelajaran adalah pada item presentasi tugas dan memperoleh skor rata-rata 3,10 dan persentasi $77,50 \%$ sehingga kesimpulan analisisnya tinggi dengan kategori "Baik".

\section{2) Kesesuaian Kurikulum dan Bahan Ajar}

Pada aspek ini yang akan dievaluasi adalah mengenai kesesuaian antara kurikulum dan bahan ajar pendidikan dan pelatihan dengan tujuan pendidikan dan pelatihan dan tema pendidikan dan pelatihan, kaitan bahan ajar/materi pendidikan dan pelatihan dengan visi dan misi Dinas Pendidikan Kabupaten Kayong Utara Provinsi Kalimantan Barat sebagai institusi pendidikan yang konsentrasi dan konsisten terhadap mutu pendidikan di Kabupaten Kayong Utara Provinsi Kalimantan Barat berusaha secara maksimal mewujudkan regulasi undang-undang, yaitu: Permendiknas Nomor I3 Tahun 2007 tentang Standar Kepala Sekolah/Madrasah dan Permendiknas Nomor 28 Tahun 2010 tentang Penugasan Guru Sebagai Kepala Sekolah/Madrasah. Dari hasil wawancara yang telah dilakukan dapat disimpulkan bahwa kurikulum yang telah ditetapkan relevan dengan tugas yang akan dilaksanakan dan implementasinya 
Isjuandi

Anan Sutisna

dalam kegiatan pendidikan dan pelatihan dapat terlaksana dengan baik sesuai dengan kriteria/standar, seperti terlihat pada grafik berikut:

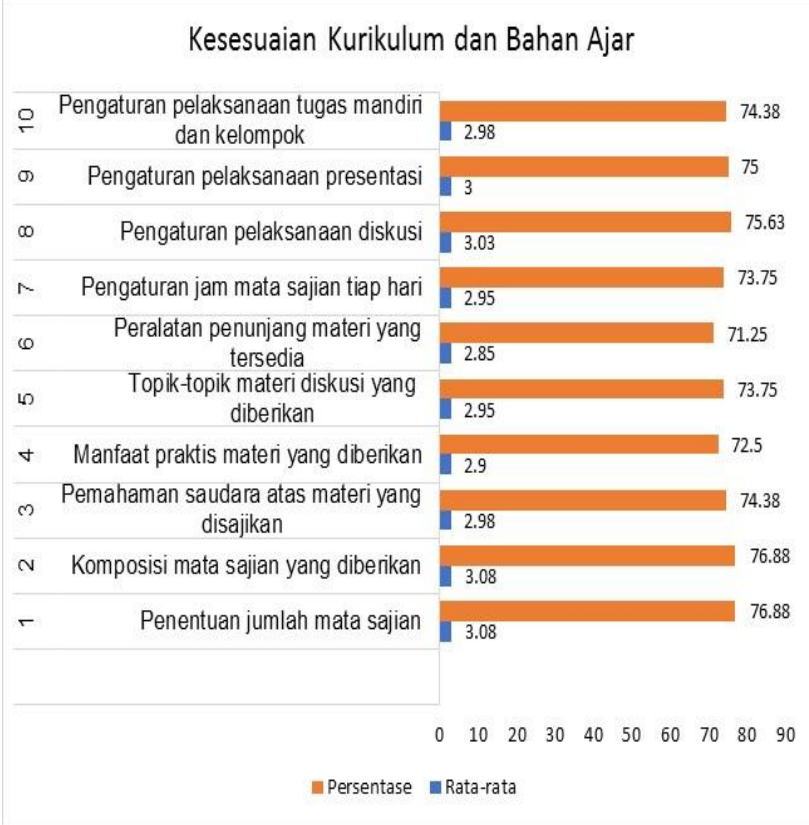

Berdasarkan grafik tersebut dapat dijelaskan bahwa evaluasi pada aspek muatan kurikulum dan bahan ajar secara keseluruhan telah sesuai kriteria yang ditunjukkan dengan perolehan nilai rata-rata 2,98 persentase $74,44 \%$ sehingga kesimpulan analisisnya tinggi dengan kategori "Baik".

\section{3) Kesesuaian Prosedur dan Metode Pembelajaran}

Hasil wawancara ini didukung dengan hasil angket terhadap kompetensi narasumber, di mana pada butir soal nomor 5 tentang kemampuan menyampaikan materi yang sesuai dengan silabus dan RPP memperoleh skor ratarata 3,03 dan persentasi $75,69 \%$. Sedangkan pada butir soal nomor 9 tentang penguasaan metode pembelajaran yang ditetapkan dalam kurikulum pendidikan dan pelatihan dengan skor rata-rata adalah 3,3I dan persentase 82,64\%. Dari perolehan skor maupun persentase tersebut maka dapat dikatakan bahwa prosedur dan metode pendidikan dan pelatihan mendapat nilai yang tinggi dengan dikategorikan "Baik".
Evaluasi Program Pendidikan dan Pelatihan Calon Kepala Sekolah di Kabupaten Kayong Utara Provinsi

Kalimantan Barat

\section{d. Product (Produk)}

Evaluasi Produk (Hasil) sebagai evaluasi yang mengukur, menafsirkan keberhasilan pencapaian tujuan yang mengarah kepada peningkatan kinerja lulusan dan kuantitas lulusan yang telah diangkat maupun belum diangkat sebagai kepala sekolah, menilai dan mengumpulkan data membandingkan kriteria yang ditetapkan dalam tujuan dengan kenyataan yang terdapat di lapangan dan pertimbanganpertimbangan dari hasil yang terkait dengan konteks, input, dan proses lalu merumuskan penafsiran secara rasional.

\section{I) Keberhasilan Pencapaian Tujuan Pendidikan dan Pelatihan Calon Kepala Sekolah}

Ada beberapa kriteria atau standar yang dapat dijadikan tolok ukur agar seorang kepala sekolah dapat dikatakan profesional, di antaranya adalah memiliki kompetensi sesuai dengan standar minimum kemampuan sebagaimana dalam Permendiknas Nomor 13 Tahun 2007. Kompetensi dimaksud adalah Sikap dan Perilaku terdiri dari: Kedisiplinan, Kerjasama, Prakarsa, dan Tanggungjawab. Sedangkan Kompetensi Kepemimpinan terdiri dari: Kepribadian, Sosial, Kewirausahaan, dan Kepemimpinan. Berdasarkan angket diperoleh hasil sebagai berikut:

\section{a) Penguasaan Pengetahuan (Knowledge)}

Secara umum hasil angket kompetensi terhadap penguasaan pengetahuan calon kepala sekolah yang telah mengikuti pendidikan dan pelatihan berada dalam kategori baik, hal ini sesuai dengan kriteria evaluasi yang telah ditetapkan, di mana sesuai dengan hasil wawancara dengan peserta menunjukkan para calon kepala sekolah dapat menguasai pengetahuan secara teoretis atau materi pendidikan dan pelatihan yang disampaikan oleh narasumber. 


\section{b) Penguasaan Sikap dan Perilaku (Attitude)}

Secara keseluruhan hasil angket sikap dan perilaku calon kepala sekolah pasca mengikuti pendidikan dan pelatihan dapat dilihat pada grafik berikut:

\section{Penguasaan Sikap dan Prilaku}

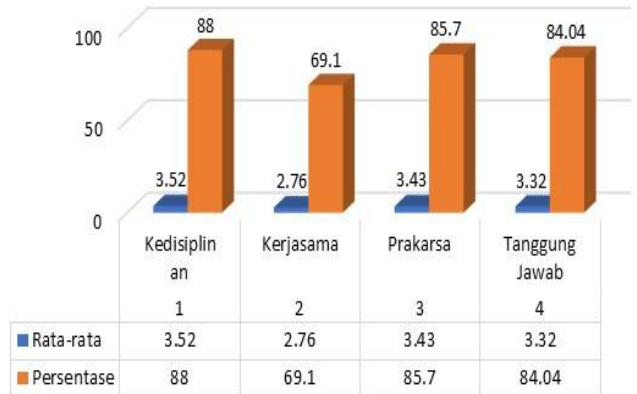

" Rata-rata $\|$ Persentase

Dengan kesimpulan bahwa penguasaan sikap dan perilaku dengan kategori sangat baik persentase sangat tinggi.

\section{c) Penguasaan Keterampilan (Skill)}

Dimensi-dimensi yang dievaluasi pada aspek penguasaan keterampilan (Skill) adalah kompetensi Kepemimpinan yang terdiri dari dimensi: kepribadian, manajerial, kewirausahaan, supervisi, dan sosial. Hasil angket tentang kompetensi kepemimpinan dapat dilihat dalam grafik berikut:

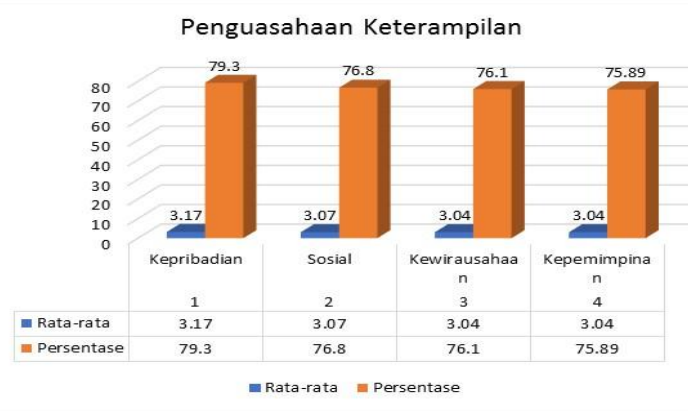

Berdasarkan data pada grafik tersebut secara umum peneliti menarik suatu kesimpulan bahwa, ternyata kompetensi calon kepala sekolah yang telah mengikuti pendidikan dan pelatihan calon kepala sekolah rata-rata masuk dalam kategori "Baik" dengan persentase tinggi.

Dari hasil wawancara dengan beberapa informan tersebut, dapat peneliti simpulkan bahwa kinerja lulusan pendidikan dan pelatihan calon kepala sekolah yang telah diangkat menjadi kepala sekolah memperlihatkan telah memiliki kompetensi pengetahuan, sikap dan prilaku, dan keterampilan yang lebih, hal ini dapat dilihat dari cara pengelolaan sekolah, pencapaian prestasiprestasi di sekolah, dan manajemen kerja yang sangat baik dibandingkan dengan kepala sekolah yang tidak mengikuti pendidikan dan pelatihan calon kepala sekolah.

\section{d) Pengangkatan/Penempatan Calon Kepa la Sekolah Sebagai Kepala Sekolah}

Berdasarkan data pada komponen pencapaian tujuan tersebut secara umum peneliti menarik suatu kesimpulan bahwa, ternyata kompetensi calon kepala sekolah yang telah mengikuti pendidikan dan pelatihan calon kepala sekolah rata-rata masuk dalam kategori "Baik/ Memadai" dan layak untuk diangkat menjadi kepala sekolah.

Dari hasil studi dokumen dapat disimpulkan bahwa pendidikan dan pelatihan calon kepala sekolah yang dilaksanakan oleh dinas pendidikan Kabupaten Kayong Utara Provinsi Kalimantan Barat dari tahun 2012 sampai dengan tahun 2014 telah menghasilkan 73 calon kepala sekolah. Yang sudah diangkat menjadi kepala sekolah berjumlah 63 orang dengan persentase 86,3\% kategori sangat tinggi.

\section{e. Outcomes (Dampak)}

Peneliti juga melakukan angket terhadap para calon kepala sekolah yang telah diangkat menjadi kepala sekolah di lingkungan Dinas Pendidikan Kabupaten Kayong Utara Provinsi Kalimantan Barat dalam mengukur seberapa jauh dampak pendidikan dan pelatihan calon kepala sekolah terhadap kinerja lulusan setelah diangkat sebagai kepala sekolah. Berikut hasil angket dari 25 butir soal dengan 4 opsi pilihan jawaban dan 40 orang kepala sekolah sebagai responden yang telah diangkat dari hasil lulusan pendidikan dan 
Isjuandi

Anan Sutisna

pelatihan calon kepala sekolah. Dari data angket tersebut yang terhimpun memperoleh total skor 3029 masuk dalam kelas interval (2502 sampai dengan 3252) sehingga dampak pendidikan dan pelatihan calon kepala sekolah terhadap kinerja lulusan setelah diangkat mempunyai pangaruh "positif", dengan persentase pencapaian kinerja 75,93\% dengan kategori "Sangat Baik" yang menunjukkan kinerja yang signifikan.

\section{Kesimpulan}

Dari hasil penelitian yang telah dilakukan diperoleh kesimpulan bahwa manajemen pelaksanaan pendidikan dan pelatihan calon kepala sekolah di Dinas Pendidikan Kabupaten Kayong Utara Provinsi Kalimantan Barat telah berjalan secara efektif sesuai dengan prosedur yang telah ditetapkan sehingga kriteria dalam evaluasi dapat terpenuhi. Model evaluasi CIPPO dipilih untuk alasan kesempurnaan informasi yang dihasilkan secara menyeluruh dan komprehensif oleh model evaluasi ini. Tahapan penelitian evaluasi mencakup empat tahapan, yaitu: (I) deskripsi mengenai penentuan responden atau sumber data; (2) metode pengumpulan data; (3) instrumen pengumpul data; dan (4) deskripsi mengenai analisis data.

Evaluasi model CIPPO terdiri dari: contexts, input, process, product, dan outcome(s), dari kelima komponen atau tahapan dalam evaluasi program pendidikan dan pelatihan calon kepala sekolah diperoleh hasil sebagai berikut: I) Komponen contexts program pendidikan dan pelatihan calon kepala sekolah telah sesuai dengan kriteria yang telah ditetapkan, walaupun masih perlu ada sosilaisasi lebih lanjut, 2) Komponen input program pendidikan dan pelatihan calon kepala sekolah tahun 2012 sampai dengan tahun 2015 di Dinas Pendidikan Kabupaten Kayong Utara Provinsi Kalimantan Barat telah sesuai dengan kriteria keberhasilan, 3) Komponen process penyelenggaraan pendidikan dan pelatihan calon kepala sekolah di Kabupaten Kayong Utara Provinsi Kalimantan Barat relevan dan sesuai dengan kriteria yang telah ditetapkan, 4) Komponen product program pendidikan dan pelatihan para calon kepala sekolah memperoleh penilaian dengan kategori "Baik", hal ini sudah
Evaluasi Program Pendidikan dan Pelatihan Calon Kepala Sekolah di Kabupaten Kayong Utara Provinsi

Kalimantan Barat

sesuai dengan kriteria evaluasi yang telah ditetapkan, dan 5) Komponen outcome(s) program pendidikan dan pelatihan calon kepala sekolah mempunyai dampak positif dan signifikan terhadap, kinerja kepala sekolah dan lingkungan masyarakat sekolah maupun bagi kepala sekolah itu sendiri.

Dari beberapa kesimpulan di atas maka peneliti dapat merekomendasikan beberapa hal untuk dapat ditindaklanjuti oleh pengambil kebijakan, baik oleh lembaga pendidikan dan pelatihan, pemerintah daerah maupun Dinas Pendidikan Kabupaten Kayong Utara Provinsi Kalimantan Barat. Rekomendasi tersebut antara lain:

I. Kepala LPMP Provinsi Kalimantan Barat selaku lembaga yang memfasilitasi narasumber/ fasilitator untuk dapat melakukan komunikasi yang intensif dan sosialisasi adanya regulasi Permendiknas Nomor 13 Tahun 2007 tentang Standar Kualifikasi dan Kompetensi Kepala Sekolah dan Permendiknas Nomor 28 Tahun 2010 tentang Guru Yang Diberi Tugas Tambahan Sebagai Kepala Sekolah kepada Jajaran Pemerintah Daerah bukan saja pada Dinas Pendidikan, tetapi juga kepada Bupati, DPRD, maupun BKD.

2. Kepala Dinas Pendidikan Kabupaten Kayong Utara Provinsi Kalimantan Barat untuk dapat memprioritaskan pengangkatan kepala sekolah yang telah mengikuti pendidikan dan pelatihan calon kepala sekolah dan dapat mengintervensi pengaturan jadwal pelaksanaan OJL yang lebih baik agar pada saat pelaksanaan OJL tidak merugikan KBM siswa.

3. Panitia penyelenggara perlu melakukan pembenahan dan perbaikan internal terkait dengan sarana prasarana dan pelayanan penyelenggaraan pendidikan dan pelatihan calon kepala sekolah.

4. Guru dan alumni pendidikan dan pelatihan calon kepala sekolah hendaknya lebih menjaga konsistensi kinerja positif di lingkungan kerjanya, agar terhindar dari kesan bahwa pendidikan dan pelatihan hanya kegiatan formalitas dalam menduduki jabatan kepala sekolah, karena telah diberikan amanah dan kepercayaan untuk menambah ilmu serta pengalaman melalui pendidikan dan pelatihan. 
Isjuandi

Anan Sutisna
Evaluasi Program Pendidikan dan Pelatihan Calon Kepala Sekolah di Kabupaten Kayong Utara Provinsi Kalimantan Barat

\section{Daftar Pustaka}

Akhyar. M, Penerapan Riset Evaluasi Dalam Bidang Pendidikan: Sebuah Pedoman Praktis. Jurnal Pendidikan Agama Islam, Vol. IV, No. I, 2007.

Fitzpatrick, J.L., Sanders, J.R., \&Worthen, B.R. (2004). Program Evaluation: Alternative Approaches and Practical Guidelines. Boston: Pearson Education.

Kemendikbud, Juklak Pemerolehan Sertifikat dan NUKS, LP2KS, 2013. Juklak Pendidikan dan Pelatihan Calon Kepala Sekolah, LP2KS, 2013.

Mulyatiningsih, Endang, Metode Penelitian Terapan Bidang Pendidikan. Bandung: Alpabeta, 2013.

Mulyasa, Menjadi Kepala Sekolah Profesional, Bandung: Remaja Rosdakarsa, 20I I.
Permendiknas, Nomor 13 Tahun 2007 tentang Standar Kepala Sekolah/Madrasah.
-----------, Nomor 28 Tahun 2010 tentang Penugasan Guru Sebagai Kepala Sekolah/Madrasah

Suhardiman, Budi, Studi Pengembangan Kepala Sekolah: Konsep dan Aplikasi. Jakarta: Rieneke Cipta, 2012.

Stufflebeam, Daniel L, dan Athony J. Shinkfield, Systematic Evaluation: A Self-Instructionl Guide to Theory and Practice. Boston: Kluwer Nijhoff Publishers Group, 1988.

Madaus, G.F,\& Kellaghan, T. (2002). Evaluation Models: Viewpoints on Educational and Human Services Evaluation. Ed. Daniel L. Stufflebeam, George F. Madaus dan Thomas Kellaghan. New York: Kluwer Academic. 